CARTAS AL EDITOR Rev Chil Salud Pública 2014; Vol 18 (1): 112-113

\section{COMITÉ EDITORIAL REVISTA CHILENA DE SALUD PÚBLICA}

\section{Estimado Jorge:}

Escribo por tu intermedio a la Revista Chilena de Salud Publica por tu preocupación acerca de los maestros de nuestra medicina chilena, con el sentimiento de tristeza profunda por la partida, este 18 de julio de 2013, del Dr. Ernesto Medina Lois, sin duda uno de ellos.

Me place encontrar que justamente en el último número de vuestra revista aparece un artículo escrito durante la dictadura, en que en forma lúcida y científica aboga proféticamente por la absoluta necesidad de la supervivencia de la esencia del Servicio Nacional de Salud, o las consecuencias graves para la salud de los chilenos ante su inminente desaparición, dada las políticas emergentes en ese año. Creo que eso retrata, para alguien como yo de un pensamiento político de izquierda, a un médico valiente y firme en sus conocimientos ante un gobierno militar que incluía a un familiar directo en la cúpula.

El suscrito lo conoció en los cruciales años setenta primero como alumno, luego como becario, más tarde como académico de su cátedra. Mi deseo es dar testimonio de un medico, académico y administrador ejemplar.

La primera imagen que me conformó en mi vida académica posterior fue encontrar a un profesor extraordinariamente preparado en cada temática que abordara. Debo decir que abarcaban todo el espectro de la medicina preventiva en su cruce con la medicina clínica y en su cruce con la medicina social como salud pública. Sus publicaciones sin duda avalan su dedicación.

Como los primeros becados mixtos, fuimos recibidos en su cátedra de Medicina Preventiva, el Dr. Curt Lemesch y el Dr. Ramiro Molina, con el mayor interés por parte del Dr. Medina y su equipo, entre quienes destacaba la Dra. Ana María Kaempffer, en guiarnos tutorialmente, pero al mismo tiempo en facilitar administrativa y académicamente las iniciativas que cada uno de los tres teníamos sobre nuestro aporte a la medicina nacional.

El Dr. Lemesch pudo hacerlo en el plano de la medicina interna con el Dr. Litvac, epidemiología del bocio e introducción de la sal yodada y la salud en el trabajo; el Dr. Molina, en el desarrollo de metodologías educativas y de atención integral a las embarazadas en general y más tarde de la adolescente. Por mi parte me apoyó decididamente en la creación del consultorio docente Eneas Gonel, donde pude probar metodologías de enseñanza en la atención primaria, incluyendo la participación comunitaria que encabezaba en el área norte el Dr. Roberto Belmar. En este difícil proyecto recibí las reflexiones, las aprobaciones y la colaboración como autoridad universitaria para apoyar sin restricciones este proyecto piloto, que permitió formar a numerosos estudiantes y replicar el modelo a nivel nacional y en mi exilio en México.

Durante los movimientos universitarios del 68, estando en posiciones opuestas, admiré en ese entonces y hoy, su respeto total a la diversidad política en un momento de crisis universitaria. Tal como ocurriría con la dictadura, se concentró con mayor intensidad en sus tareas académicas antes 
que convertirse en un activo impugnador de los movimientos sociales, que a mi entender se movían más bien cerca de los límites de su visión social médica.

Cuando asumió el gobierno de la Unidad Popular, aunque me trasladé al Área Central, seguí teniendo un lugar en su cátedra y tuvimos oportunidad de reflexionar sobre los acontecimientos difíciles que se vivían. Noté su interés por entender los cambios que se sucedían, incluyendo, como se lee en el artículo citado, oponerse a políticas de privatización, y nunca observé medidas de presión a algún miembro del equipo de otra visión política, y que hasta la fecha dan fe de que asi ocurrió. Del mismo modo cuando se invadieron los espacios académicos por fuerzas militares expresó su tristeza y asombro. Todo ello lo valoré siempre. En mi caso, cuando desde el exilio necesité validar documentos extraviados, personalmente atendió la búsqueda de algunos y asumió ante los perdidos definitivamente la responsabilidad de firmar los que los reemplazaron, gesto que fue definitivo para mi inserción académica en el extranjero y que resulta inolvidable en plena represión gubernamental y universitaria.

Finalizo señalando que no podía dejar de expresar públicamente a través de su revista este testimonio hacia un maestro, aunque fuera en el momento de su partida.

Esperando que estas palabras se sumen al reconocimiento que pueda hacerse en el futuro próximo.

Dr. Alfredo Hidalgo San Martín Guadalajara, México, 18 de julio de 2013 